\title{
A Pre-feasibility Study of Wind Resources in Vadravadra, Gau Island, Fiji
}

\author{
Rishal Amar Singh \\ College of Engineering, Science and Technology, Fiji National University, Fiji
}

Copyright (C) 2015 Horizon Research Publishing All rights reserved.

\begin{abstract}
Gau is one of the many rugged, volcanic Islands in Fiji .Averaged 10 minutely wind speed and direction data of Vadravadra settlement was supplied by Fiji Department of Energy (DoE) and the site wind characterizing was done. Considering the surface roughness, obstacle condition and terrain information of the island, a micro-scale prediction has been done using the Wind Atlas Analysis and Application Program (WAsP) to develop an annual wind atlas and also a wind resource map which shows that at $50 \mathrm{~m}$ height, the annual wind speed over Southern Gau varies from 8.42 to $14.69 \mathrm{~m} / \mathrm{s}$. The Southern Eastern sides of Gau appear to be promising for wind electricity generation using Vergnet $275 \mathrm{~kW}$ wind turbines where wind power density at a height of $50 \mathrm{~m}$ or higher is found to be around $1128 \mathrm{~W} / \mathrm{m}^{2}$ (average) annually. The total energy produced from using eight Vergnet $275 \mathrm{~kW}$ turbine generators was $13.320 \mathrm{GWh}$ and the COE borne was $\$ 0.55 / \mathrm{kWh}$.
\end{abstract}

Keywords Surface Roughness, Obstacle, WAsP, Wind Atlas, Vergnet, COE

\section{Introduction}

In light of the threefold global crisis mankind is facing currently - the energy crisis, the finance crisis and the environment/climate crisis - it is becoming increasingly obvious that wind energy offers solutions to all of these huge challenges, offering a domestic, reliable, affordable and clean energy supply. In the mid to long term it is clear that wind energy investments will rather be strengthened due to their low-risk character and additional economic benefits [1]. Investment in a wind turbine today means that the electricity generation cost is fixed to the major extends over the lifetime of the wind turbine. Wind energy implies no expenses on fuel and operation and maintenance costs are usually well predictable and rather marginal, in relation to the overall investment.

Fiji is a developing country with an ever increasing energy demand. In 2006, the bill for imported fuel escalated to \$F1.021billion, becoming 33 per cent of Fiji's total import bill of \$F3.119billion [2]. A significant proportion of this fuel is used for power generation, something that takes on a critical importance when there are water shortages at Monasavu Hydro Dam. These shortages and the rising demand for power have inevitably led to escalating fuel costs for Fiji's energy producer and supplier, Fiji Electricity Authority (FEA). In 2006 for instance, the Authority spent $\$ 98.6$ million on diesel fuel for its generators, as compared to \$49.9million in 2004 and a mere \$19million in 2001[2]. Spending has come to a saturation point and FEA now seeks cost-effective and stable forms of energy generation.

In the search for RE power, the most important decisions are concerned with exploitation of local, clean and sustainable energy resources. Fiji has high potential for wind [3] but the exact determination of wind energy potential of a given site depends very much on the meteorological measurements of the wind direction, velocity, and solar irradiation for that area. Unfortunately, in many areas of Fiji, it is difficult to obtain such data.

This report examines the wind characteristics and potential power generation from wind at and around Vadravadra, the main settlement area in Gau using WAsP, a computer program used to calculate and determine potential of wind farming in a given area. WAsP has been successfully utilised in the rugged, forest terrain in the Kutubdia Island, Bangladesh to investigate the prospective of developing wind farms by the Bangladesh Centre for Advanced Studies (BCAS) [4]. WAsP has been also used by A.S. Ahmed Shata of Institute of Energy and Automation Technology, for feasibility studies around coast of Mediterranean Sea in Egypt [5]. Using of WAsP for estimating wind power potentials of various sites around the globe is well documented and is wholly due to the fact the WAsP is precise, versatile and provides virtually all what is needed for setting up wind farming in any given landscape.

The primary use of WAsP has been for siting of wind turbines world-wide, single or in farms. Over the decade it has been in use, it has developed into a generally accepted standard for micro-siting [6]. WAsP predictions are based on wind data measured at stations in the same region. The program includes a complex terrain flow model, a roughness change model and a model for sheltering obstacles. Considering the effects for the obstacles, roughness and terrain, the WAsP develops a wind atlas for the region. The 
wind atlas is then used to predict the power density of the area in study and together with the resource grid, estimates the Net Annual Energy Production of any proposed turbine generator installations.

\section{Methodology}

Gau is an island belonging to Fiji's Lomaiviti archipelago. Located at $18.00^{\circ} \mathrm{S}$ and $179.30^{\circ} \mathrm{E}$. It covers an area of 136.1 square kilometers, with a total shoreline of 66.3 kilometers. It is mostly covered with dense forests in the interior of the islands and host many hills and mountains with maximum altitude being 738 meters.

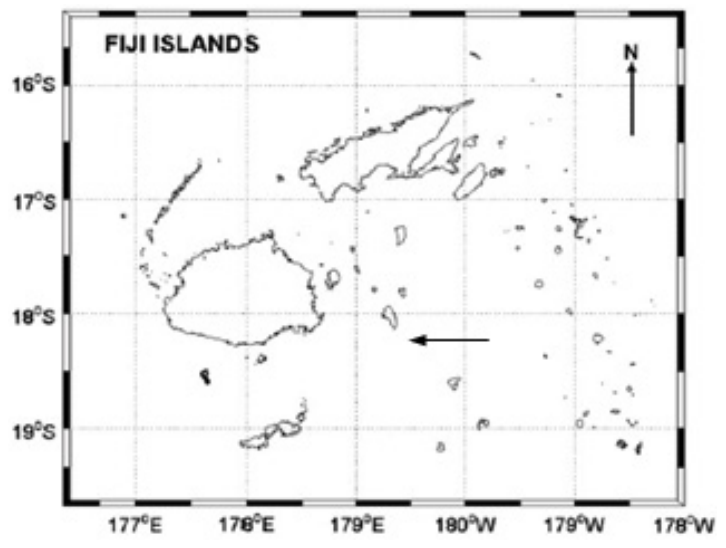

Figure 1. Map of Fiji showing studied site location

Averaged 10 minutely raw wind speed and direction data from $1^{\text {st }}$ March, 2003 to $27^{\text {th }}$ November, 2005 was analysed using WAsP to develop the region's wind atlas. The wind atlas data sets are site independent and the wind distributions have been reduced to some standard conditions. A wind rose, an output of the OWC is a diagram, which shows the temporal distribution of wind direction and azimuthal distribution of wind speed at a given location [7]. It is a convenient tool for displaying anemometer data (wind speed and direction) for siting analysis. The wind rose consists of 12 concentric circles with equally spaced radial lines (each represents a compass point). The line length is proportional to the frequency of the wind from the compass point, with the circles forming a scale. The frequency of calm conditions is indicated in the center. The longest lines identify the prevailing wind directions [7]. See Fig. 2 for the wind rose observed by the Vadravadra data monitoring center.

Obstacle groups describe objects in the vicinity of the calculation sites, which might affect the behavior of the wind at the site. Examples of sheltering obstacles encountered were buildings, and forestry. Each obstacle is defined with its position relative to north, its dimensions and porosity.

The wind rose indicates that wind was blowing mainly from South East giving an average power density of approximately $228 \mathrm{~W} / \mathrm{m}^{2}$, which is considered as a good wind potential site. Majority (95\%) of the wind lies between sectors $135^{\circ}$ and $180^{\circ}$ with an approximate speed of $6.26 \mathrm{~m} / \mathrm{s}$. This reveals that there is unobstructed wind and since the studied site is close to the sea-shore this evidences a very low turbulence. The scale Weibull parameter, A, is used to indicate how windy the site is, on average. The Weibull shape parameter, $\mathrm{k}$, tells how peaked the distribution is, i.e. if the wind speeds always tend to be very close to a certain value, the distribution will have a high $\mathrm{k}$ value, and be very peaked.

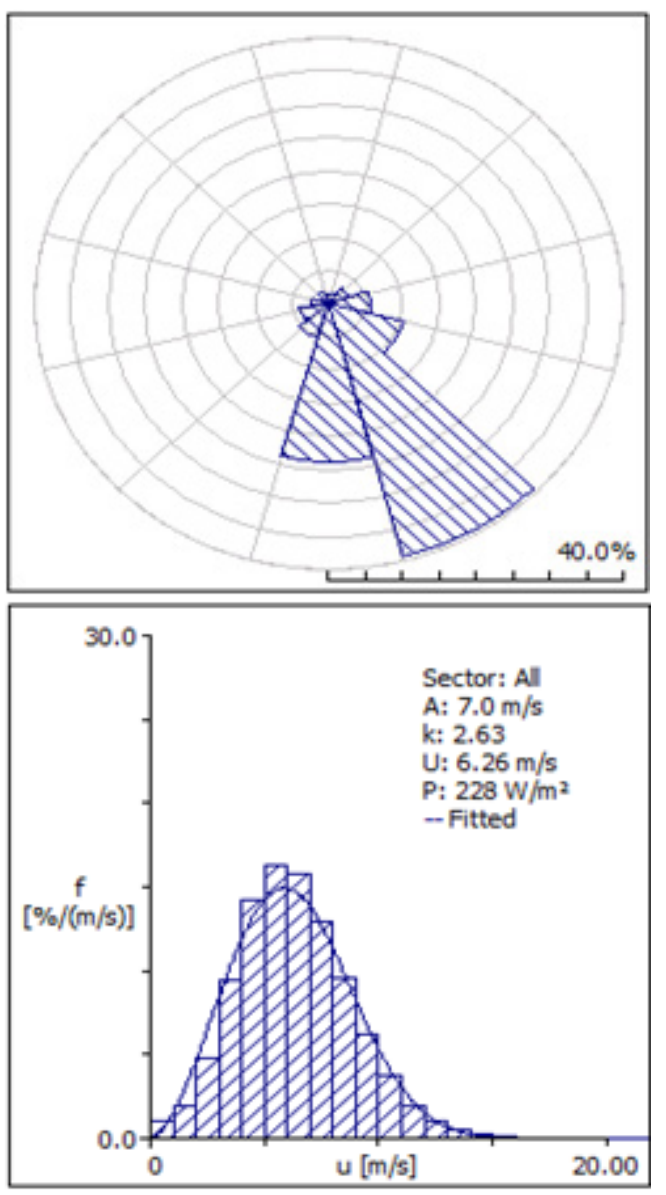

Figure 2. Wind rose and frequency distribution generated by WAsP

Vector maps were used to describe the elevation (orography) and land use (surface roughness) of the area surrounding calculation sites such as meteorological stations, reference sites, turbine sites or the sites in a resource grid [7]. The vector maps are drawn by digitizing the background contour map of the area. The Height contours and roughness lines are the fundamental components in the digitising process. Digitising defines a roughness parameter on both sides (right and left, or consequently up or down) of the contour. There are two principal lines used for digitizing are the roughness and the roughness-change lines [8]. Roughness lines are in essence, the primary line for digitizing. It is the line etched over the contour line by simply continuously left clicking on the contour line and provides roughness at either side of the contour line. Roughness-change lines however cross altitudes and caters for any roughness difference in-within. A number of roughness guidelines were met in order to have a consistent roughness description. The lines were checked for the cross points, and that they ended in a closed loop or end at a star-point (node) or ended at the map boundary to ensure that 
all roughness-lines facing the same coherent area had identical roughness lengths.

The power production of four $120 \mathrm{~kW}$ and six $80 \mathrm{~kW}$ rated turbines were estimated. The two scenarios produced the same rated power of $480 \mathrm{~kW}$. The economic and production viability of both were studied and compared. Also, the potential of wind farming using Vergnet $275 \mathrm{~kW}$ model was estimated using WAsP. Models chosen had relative low price, and features such as the cut-in, cut-out and the rated wind speeds matched the characteristics of the wind regime of the studied site. See Table 1 for full specifications and Fig. 4. for the power and thrust curves.

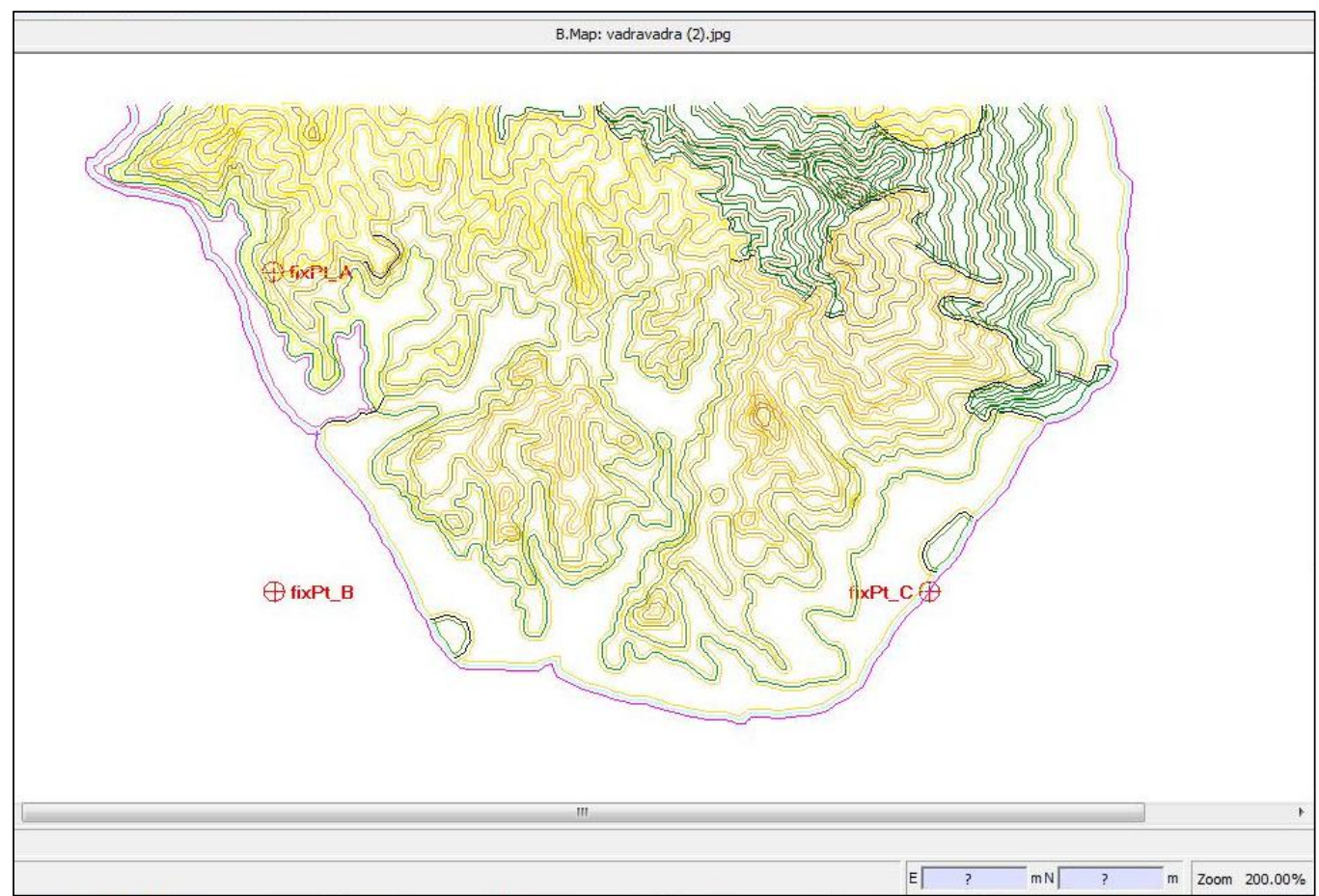

Figure 3. A fully digitized map of southern Gau. The different line colours indicate the different roughness parameters associated with particular contour lines

Table 1. Technical Specifications of the studied turbine models

\begin{tabular}{|c|c|c|c|}
\hline \multirow{8}{*}{$\begin{array}{c}\text { Fuhrlander } 80 \\
\text { FL } 80\end{array}$} & \multirow{6}{*}{ Rotor } & Turbine height & $50 \mathrm{~m}$ \\
\hline & & Diameter & $18 \mathrm{~m}$ \\
\hline & & Cut-in wind speed & $3 \mathrm{~m} / \mathrm{s}$ \\
\hline & & Rated wind speed & $13 \mathrm{~m} / \mathrm{s}$ \\
\hline & & Swept area & $254.5 \mathrm{~m} / \mathrm{s}^{2}$ \\
\hline & & Cut-out wind speed & $20 \mathrm{~m} / \mathrm{s}$ \\
\hline & Generator & Rated Power & $82 \mathrm{~kW}$ \\
\hline & & & 3 \\
\hline & & Turbine height & $50 \mathrm{~m}$ \\
\hline & & Diameter & $24 \mathrm{~m}$ \\
\hline & Retor & Cut-in wind speed & $2.8 \mathrm{~m} / \mathrm{s}$ \\
\hline Fuhrlander 120 & Rotor & Rated wind speed & $14 \mathrm{~m} / \mathrm{s}$ \\
\hline FL120 & & Swept area & $452.4 \mathrm{~m} / \mathrm{s}^{2}$ \\
\hline & & Cut-out wind speed & $25 \mathrm{~m} / \mathrm{s}$ \\
\hline & Generator & Rated Power & $123 \mathrm{~kW}$ \\
\hline & & & 3 \\
\hline & & Turbine height & $55 \mathrm{~m}$ \\
\hline & & Diameter & $32 \mathrm{~m}$ \\
\hline & & Cut-in wind speed & $3.5 \mathrm{~m} / \mathrm{s}$ \\
\hline Vergnet $275 \mathrm{~kW}$ & Rotor & Rated wind speed & $16 \mathrm{~m} / \mathrm{s}$ \\
\hline GEV MP & & Swept area & $804.2 \mathrm{~m} / \mathrm{s}^{2}$ \\
\hline & & Cut-out wind speed & $20 \mathrm{~m} / \mathrm{s}$ \\
\hline & Generator & Rated Power & $275 \mathrm{~kW}$ \\
\hline & & & 2 \\
\hline
\end{tabular}



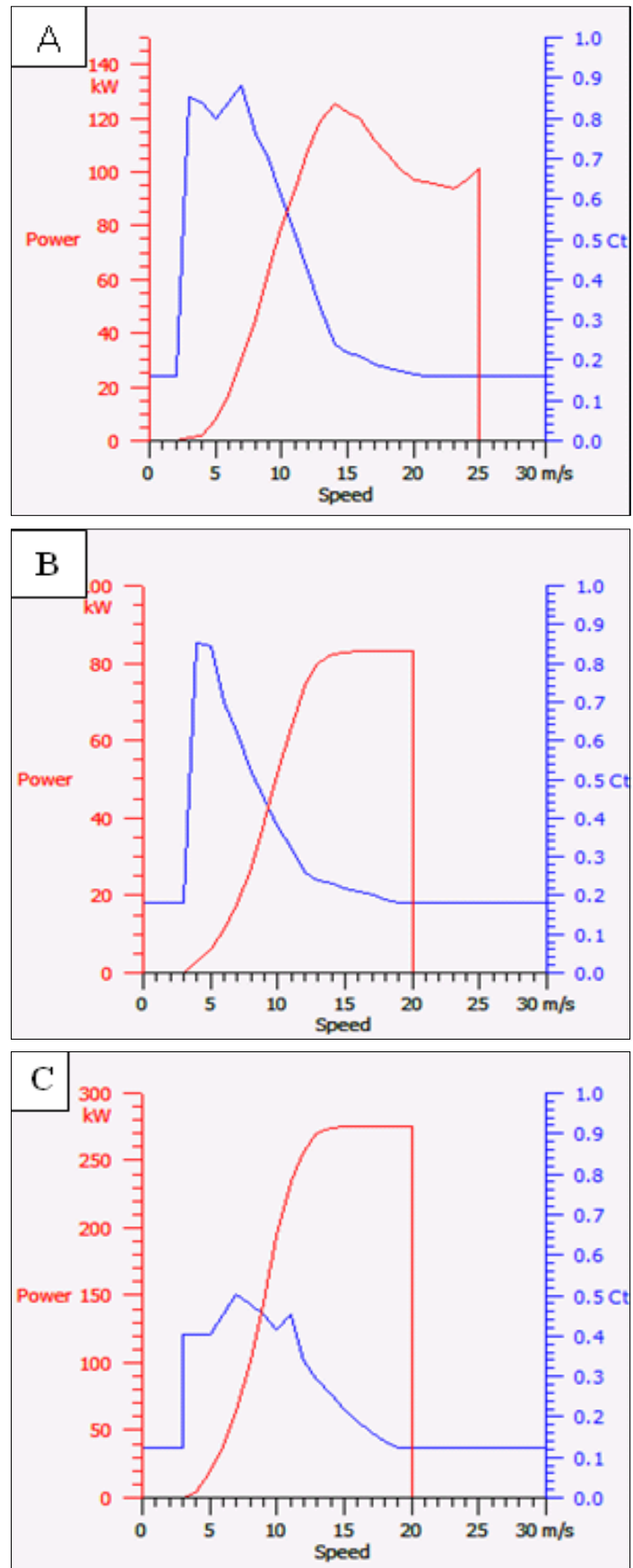

Figure 4. Turbine Editor displayed Power and Thrust Coefficient, $C_{T}$ curves for (A) FL120, (B) FL80 and (C) GEV MP
WAsP uses the power curve and thrust coefficient curves (Fig. 4) to determine the resource assessment for the area in study and thus is able to estimate annual energy productions from each turbine site. However, the AEP could also be determined using the swept area of the rotor method, the power curve method or using manufactures' estimates. However Boyle [10] derived a rough estimate of the annual electricity production $\mathrm{E}(\mathrm{kWh})$ for a number of turbines is determined from average wind speed using

$$
\mathrm{E}=\mathrm{KV}_{\mathrm{m}}^{3} \mathrm{AT}
$$

where, $\mathrm{K}$ (normally $=3.2$ ) is a factor based on typical turbine performance characteristic, $\mathrm{V}_{\mathrm{m}}$ is the mean wind speed $(\mathrm{m} / \mathrm{s})$, A is the area wept by the wind turbine blades $\left(\mathrm{m}^{2}\right)$, and $\mathrm{T}$ is the number of wind turbines [11]. The WAsP generated values and the Boyle estimates for GEV MP $275 \mathrm{~kW}$ turbines are compared in Table 2.

\section{Results and Discussion}

Wind speed and direction (10 minute average) data were used and potential of wind farming /turbine sites in Vadravadra, Gau was done using WAsP modeling which determined the wind atlas and resource grid for Southern Gau.

\subsection{WAsP Input and Output}

WAsP predicts the resource assessment after the vector map and the wind atlas is inputted before calculation. The wind resource provides an overall view of the wind climate and magnitude and distribution of wind resources at the studied turbine's hub height. An area enclosing $25 \mathrm{~km}^{2}$ was used to prepare resource grid at each point. WAsP calculates among others, AEP, Power Density, expected mean windspeed, RIX index of the terrain and the Weibull parameters in each of the 12 sector directions. Table 2 reveals that at the hub height $(50 \mathrm{~m})$ the wind speed attained is very close to the rated wind speeds of the turbine. Therefore it can be said that the studied site has a good wind regime capable of powering the models of turbines used. See Fig. $5-8$ for the WAsP outputs for the studied turbine models. 


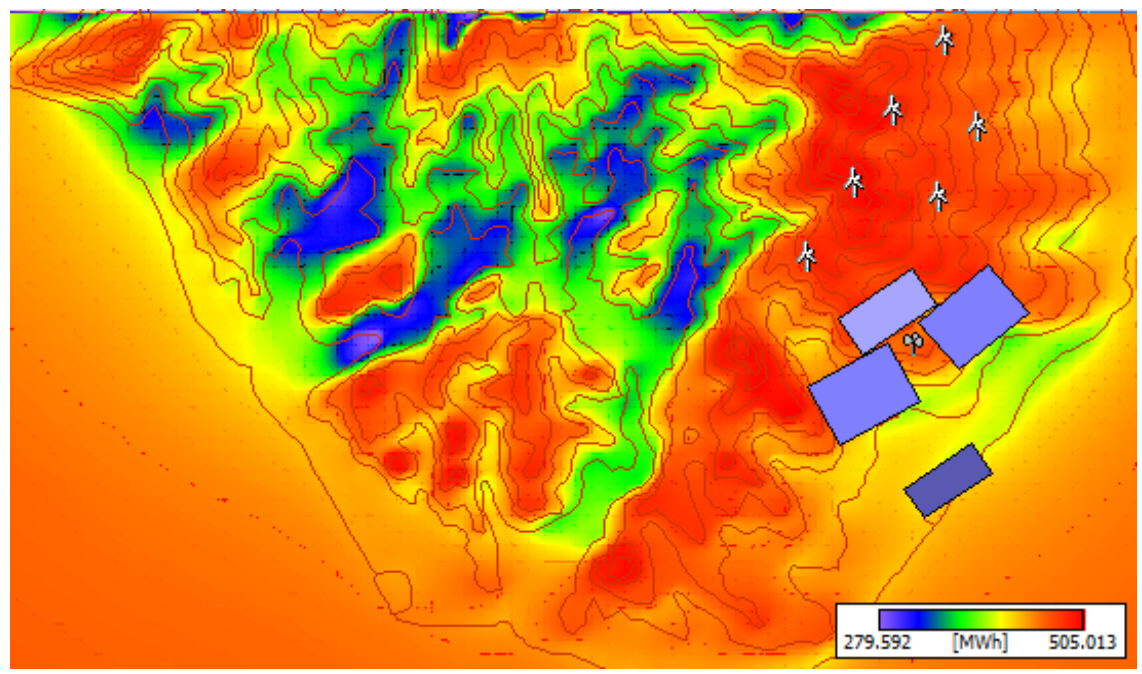

\begin{tabular}{cl} 
Maximum Value: & $505.013 \mathrm{MWh}$ \\
Minimum Value: & $279.592 \mathrm{MWh}$ \\
Mean Value: & $432.598 \mathrm{MWh}$ \\
\hline
\end{tabular}

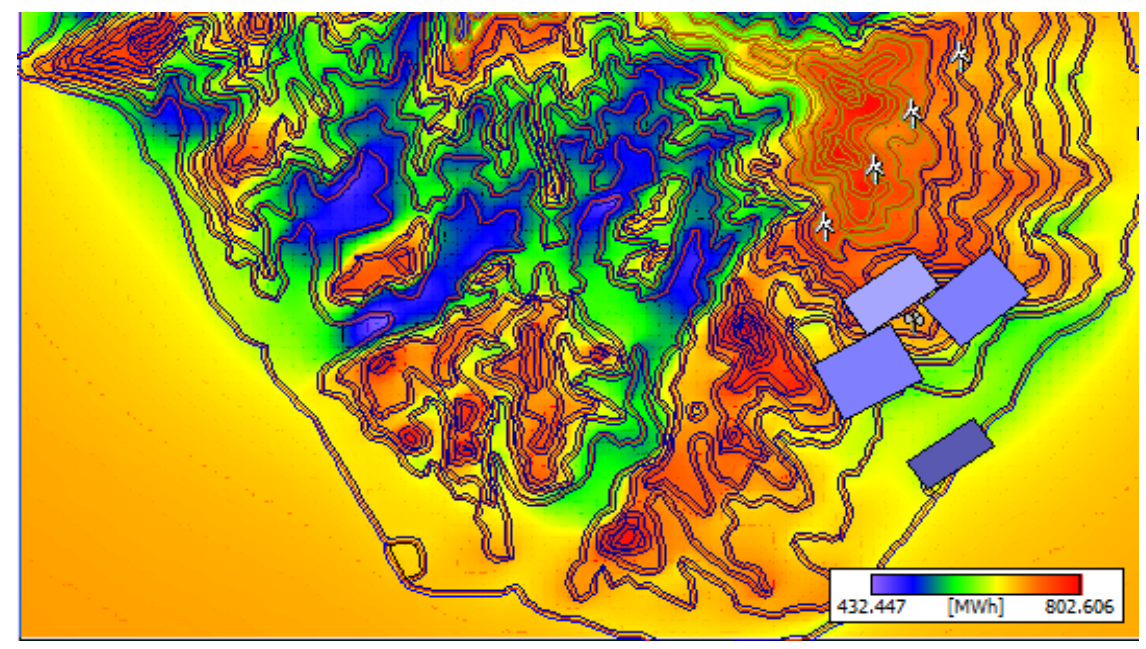

\begin{tabular}{|cl|}
\hline Maximum Value: & $802.606 \mathrm{MWh}$ \\
Minimum Value: & $432.447 \mathrm{MWh}$ \\
Mean Value: & $656.016 \mathrm{MWh}$ \\
\hline
\end{tabular}

Figure 5. WAsP predictions for Annual Energy production for FL 80 and FL 120 turbine models. Superimposed are the proposed turbine sites, the met station and the obstacles around it.

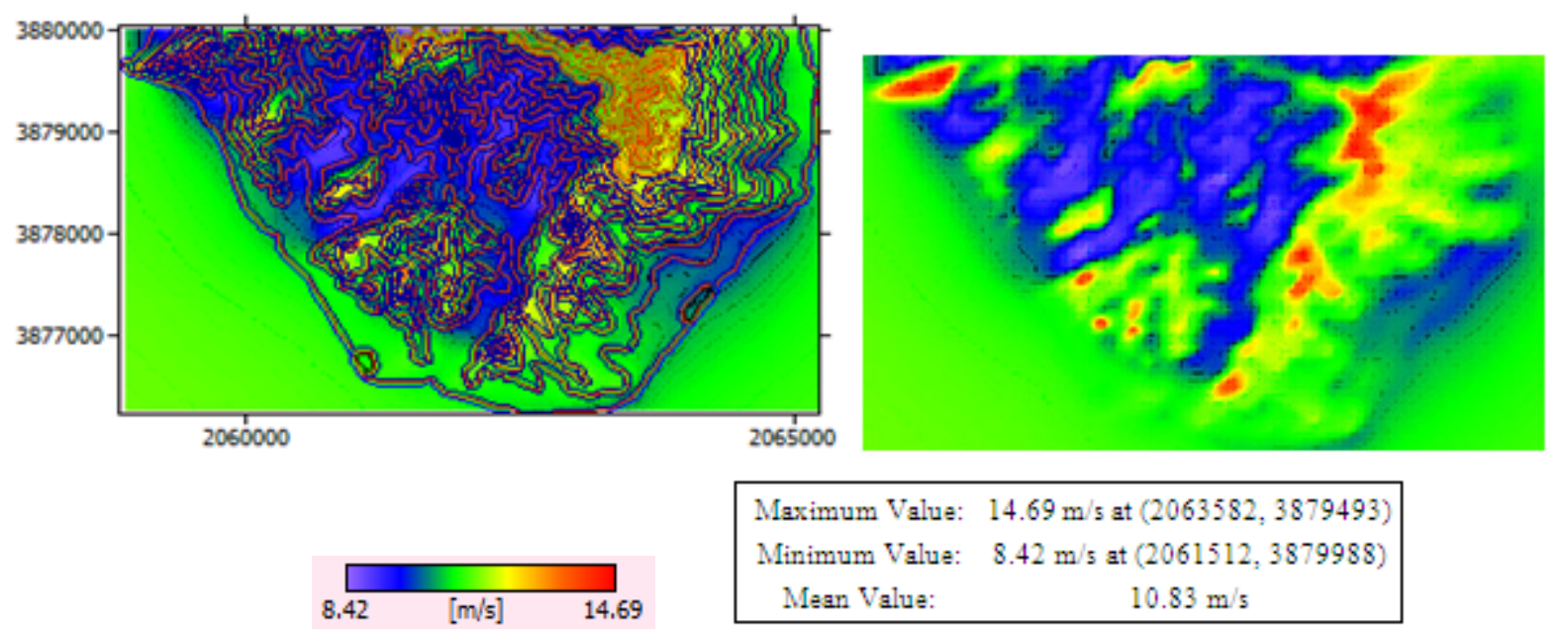

Figure 6. Mean wind speeds experienced at the GEV MP hub height. 


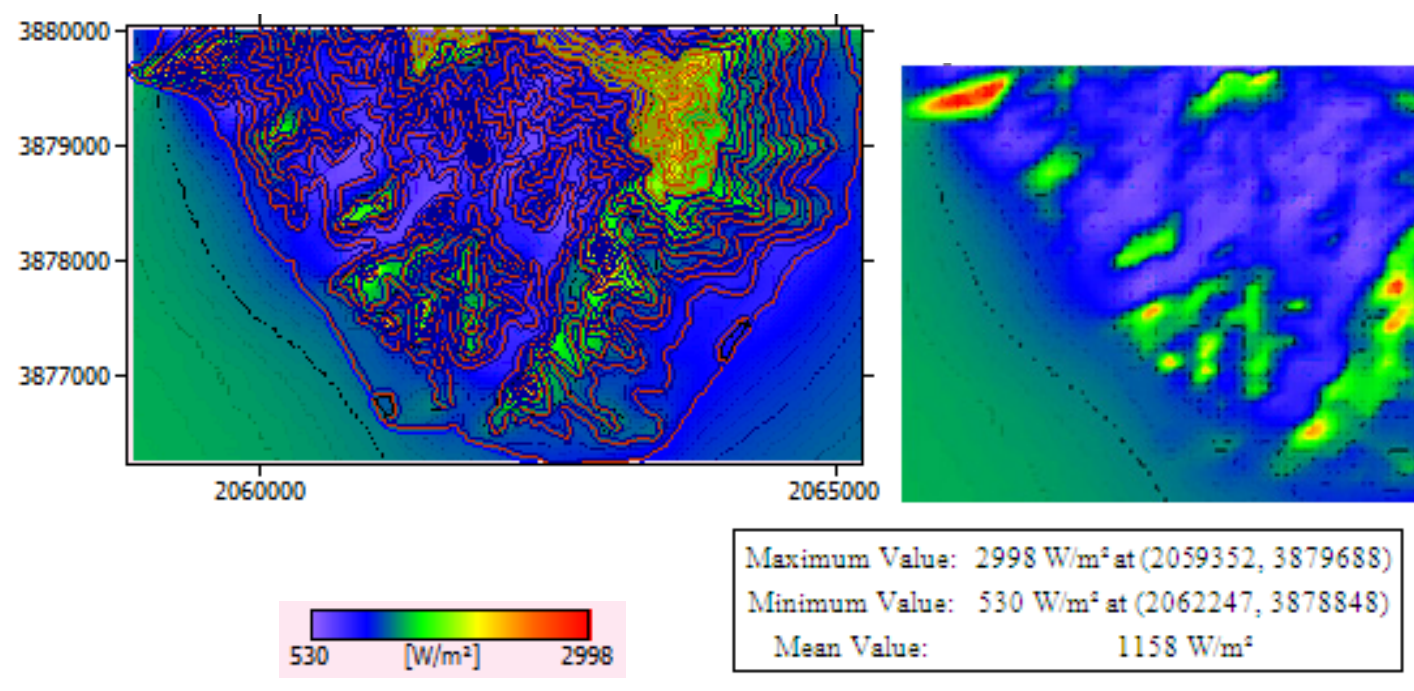

Figure 7. Predicted power density over Southern Gau

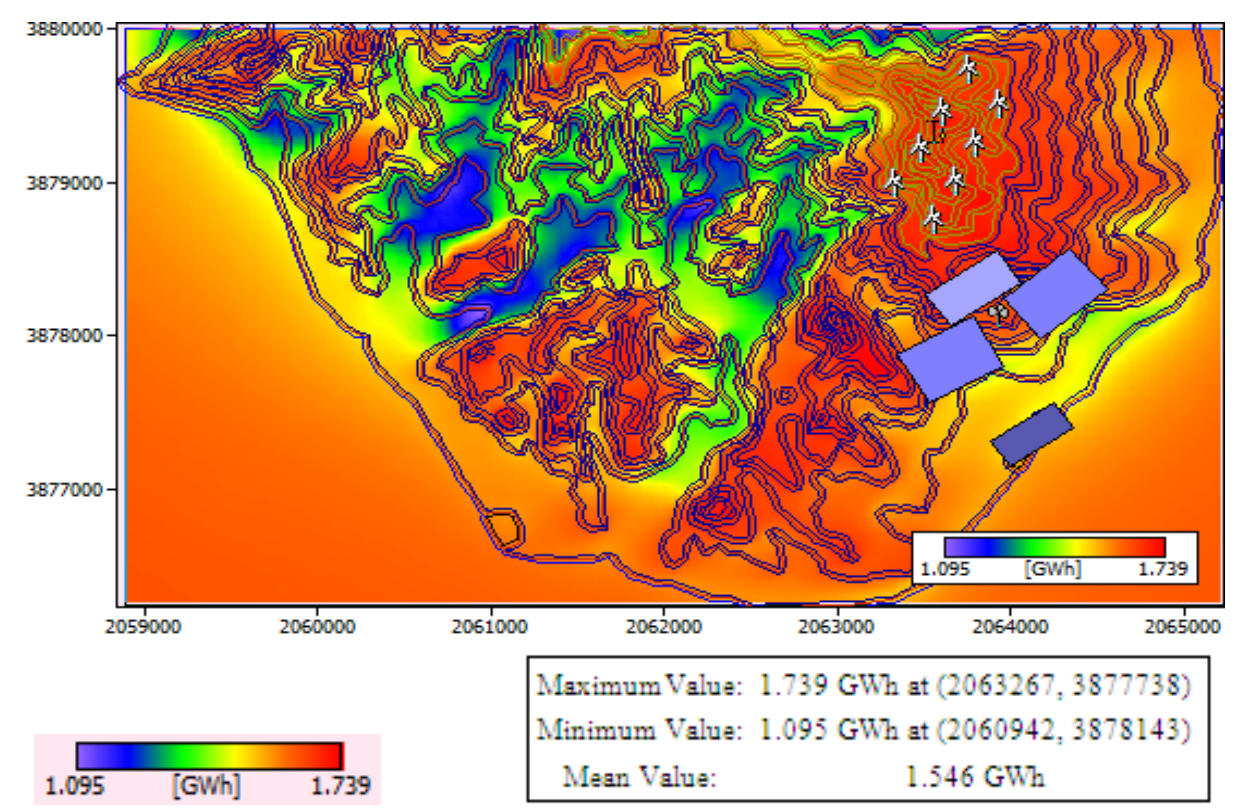

Figure 8. Predicted Annual Energy Production for the GEV MP. Superimposed are the proposed wind farm site with its reference site, the met station and the obstacles around it.

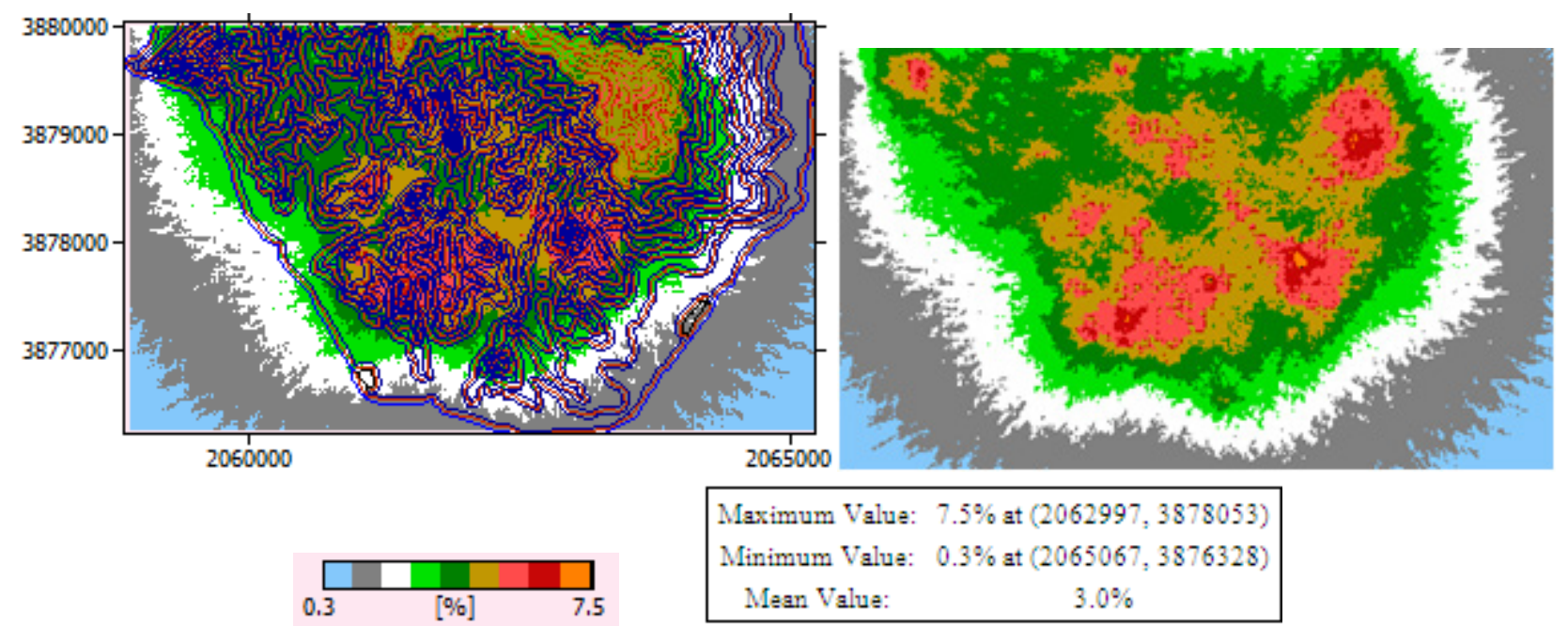

Figure 9. The Ruggedness Index for Southern Gau. A flat site will have a RIX of $0 \%$, a very complex (steep) site an RIX of $30 \%-$ meaning that about one third of the terrain is steeper than the critical slope 
Table 2. Wind turbine characterization summary

\begin{tabular}{|c|c|c|c|c|c|c|c|c|}
\hline & $\begin{array}{c}\text { Turbine } \\
1\end{array}$ & $\begin{array}{l}\text { Turbine } \\
2\end{array}$ & $\begin{array}{c}\text { Turbine } \\
3\end{array}$ & $\begin{array}{c}\text { Turbine } \\
4\end{array}$ & $\begin{array}{c}\text { Turbine } \\
5\end{array}$ & Turbine 6 & $\begin{array}{c}\text { Turbine } \\
7\end{array}$ & $\begin{array}{c}\text { Turbine } \\
8\end{array}$ \\
\hline \multicolumn{9}{|c|}{ Fuhrlander 80 kW ( FL 80 ) } \\
\hline $\mathrm{U}(\mathrm{m} / \mathrm{s})$ & 12.09 & 13.13 & 11.98 & 12.01 & 11.29 & 11.01 & - & - \\
\hline $\begin{array}{l}\text { Power } \\
\text { density } \\
\left(\mathrm{W} / \mathrm{m}^{2}\right)\end{array}$ & 1576 & 2042 & 1512 & 1579 & 1257 & 1166 & - & - \\
\hline $\mathrm{AEP}(\mathrm{MWh})$ & 483.556 & 497.084 & 491.168 & 475.041 & 473.371 & 463.626 & - & - \\
\hline \multicolumn{9}{|c|}{ Fuhrlander $120 \mathrm{~kW}$ ( FL 120 ) } \\
\hline $\mathrm{U}(\mathrm{m} / \mathrm{s})$ & 12.35 & 12.43 & 11.34 & 11.02 & - & - & - & - \\
\hline $\begin{array}{l}\text { Power } \\
\text { density } \\
\left(\mathrm{W} / \mathrm{m}^{2}\right)\end{array}$ & 1682 & 1684 & 1277 & 1189 & - & - & - & - \\
\hline $\mathrm{AEP}(\mathrm{MWh})$ & 751.938 & 764.977 & 716.935 & 691.513 & - & - & - & - \\
\hline \multicolumn{9}{|c|}{ Vergnet $275 \mathrm{~kW}$ GEV MP } \\
\hline $\mathrm{U}(\mathrm{m} / \mathrm{s})$ & 11.69 & 11.25 & 13.34 & 12.64 & 11.10 & 14.02 & 13.47 & 13.29 \\
\hline $\begin{array}{l}\text { Power } \\
\text { density } \\
\left(\mathrm{W} / \mathrm{m}^{2}\right)\end{array}$ & 1416 & 1252 & 2094 & 1809 & 1210 & 2246 & 2161 & 2141 \\
\hline AEP (MWh) & 1654 & 1627 & 1722 & 1685 & 1596 & 1687 & 1705 & 1643 \\
\hline
\end{tabular}

Table 3. WAsP and Boyle's AEP prediction for GEV MP

\begin{tabular}{cccc}
\hline $\begin{array}{c}\text { Turbine } \\
\text { classification }\end{array}$ & $\begin{array}{c}\text { Mean Wind } \\
\text { Speed at } \\
\text { turbine hub } \\
(\mathrm{m} / \mathrm{s})\end{array}$ & $\begin{array}{c}\text { WAsP } \\
\text { predicted AEP } \\
(\mathrm{GWh})\end{array}$ & $\begin{array}{c}\text { Boyle'e } \\
\text { calculated } \\
\text { value }(\mathrm{GWh})\end{array}$ \\
T1 & 11.69 & 1.654 & 4.111 \\
T2 & 11.25 & 1.627 & 3.664 \\
T3 & 13.34 & 1.722 & 6.109 \\
T4 & 12.64 & 1.685 & 5.197 \\
T5 & 11.10 & 1.596 & 3.519 \\
T6 & 14.02 & 1.687 & 7.092 \\
T7 & 13.47 & 1.705 & 6.289 \\
T8 & 13.29 & 1.643 & 6.041 \\
\hline
\end{tabular}

A vast difference between the WAsP and Boyle AEP predictions is shown in Fig. 5. The WAsP predictions remain fairly constant with marginal increases in average wind speeds. However, the increase in Boyle predictions is polynomial with degree 3 since AEP is directly proportional to the cube of the mean windspeed. Any small increment in wind speed values results in high AEP expectations. The Boyle prediction method is a very generalised model which does not consider the turbine type and specifications, nor does it account for wake or any other effects in the wind.

\subsection{Economics of the Proposed Turbine Installations}

Wind energy has a huge potential to contribute to our future energy needs, but in order for this potential to be fully realised, the technology must be both economically competitive and environmentally acceptable [12]. A series of simple economic viability calculations were performed on the studied turbine models. Firstly, a payback period was determined for each turbine design. A payback calculation compares revenue with costs and determines the length of time required to recover an initial investment [13]. The payback period (in years) is equal to the total capital cost of the wind system divided by the average annual return from the produced power. The payback period is given by:

$$
\mathrm{SP}=\mathrm{C}_{\mathrm{C}} /\left(\mathrm{E}_{\mathrm{A}} \mathrm{P}_{\mathrm{E}}\right)
$$

where $C_{C}$ is the total capital cost $(\$), E_{A}$ is the annual energy production $(\mathrm{kWh} / \mathrm{year})$, and $\mathrm{P}_{\mathrm{E}}$ is the price obtained for electricity $(\$ / \mathrm{kWh})$. $\mathrm{P}_{\mathrm{E}}$ is assumed to be $\$ 0.23$ as this is the current unit price of energy sold by FEA. The cost of energy, $\mathrm{COE}$, is perhaps the most defining economic parameter of each energy resource investment. It is, in this case, defined as the unit cost to produce energy (in $\$ / \mathrm{kWh}$ ) from the wind energy system. Generally, it is the quotient of the total operating costs and the energy produced. The general formula for $\mathrm{COE}$ calculations is;

$$
\mathrm{COE}=\left[\left(\begin{array}{ll}
\mathrm{C}_{\mathrm{C}} & \mathrm{x} F \mathrm{FC}
\end{array}\right)+\mathrm{C}_{\mathrm{O \& M}}\right] / \mathrm{E}_{\mathrm{A}}
$$

where $\mathrm{C}_{O \& M}$ is the average annual operation and maintenance cost and FCR is the fixed charge rate. It is assumed that the installations are fully funded by aid. Therefore, there are no interests to loans to be paid hence FCR is taken as unity. The $\mathrm{C}_{O \& M}$ is taken as $2 \%$ of the initial capital cost.

Table 4 shows the Payback Period and the COE analysis of the different turbines. 
Table 4. Table of Economics of the Studied WTGs

\begin{tabular}{|c|c|c|c|c|c|c|}
\hline WTG & $\begin{array}{l}\text { Total capital + } \\
\text { installation } \\
\text { costs } \\
\text { (\$) }\end{array}$ & $\begin{array}{c}\mathrm{O} \& \mathrm{M} \text { costs } \\
(\$ / \mathrm{yr})\end{array}$ & $\begin{array}{l}\text { Total Annual } \\
\text { Energy } \\
\text { Production } \\
\text { AEP (MWh) }\end{array}$ & $\begin{array}{c}\text { Electricity sales } \\
\text { per year } \\
(\text { million } \$ / y r)\end{array}$ & $\begin{array}{l}\text { Payback } \\
\text { Time }\end{array}$ & $\begin{array}{l}\text { C.O.E } \\
(\$ / \mathrm{kWh})\end{array}$ \\
\hline $\begin{array}{c}\text { Fuhrlander } 80 \\
\text { kW } \\
(\text { FL } 80)\end{array}$ & $\begin{array}{c}\$ 420000 \\
X \\
6\end{array}$ & $\$ 50400$ & 2883.846 & 0.663284 & 3.87 years & $\$ 0.89$ \\
\hline $\begin{array}{c}\text { Fuhrlander } 120 \\
\text { kW } \\
(\text { FL 120) }\end{array}$ & $\begin{array}{c}\$ 625000 \\
X \\
4\end{array}$ & $\$ 50000$ & 2925.363 & 0.672833 & 3.76 years & $\$ 0.87$ \\
\hline $\begin{array}{l}\text { Vergnet } 275 \mathrm{~kW} \\
\text { ( GEV MP) }\end{array}$ & $\begin{array}{c}\$ 900000 \\
X \\
8 \\
\end{array}$ & $\$ 144000$ & 13320 & 3.063600 & 2.40 years & $\$ 0.55$ \\
\hline
\end{tabular}

It is noted that all models studied were feasible in the studied area. Vergnet GEV MP model however, produced the lowest Cost of Energy of $\$ 0.55 / \mathrm{kWh}$. The cost incurred by FEA now to run their diesel generators to supply half of the nation's energy demand is $\$ 0.68 / \mathrm{kWh}$ [2]. The proposed installation is economical and the costs incurred throughout the life of the turbines would be minimal and fairly constant. In addition, using the current unit of electricity charged by FEA ,the payback period is less than three years. Thereon after, the unit price could be lowered.

Moreover, a complete economic study of a proposed wind energy system should include a series of sensitivity studies. A sensitivity analysis reveals the sensitivity of the model to parameter variations. Specifically, each parameter of interest is varied around some central or 'best estimate'. Fig. 10 shows a spider graph showing sensitivity plots for the GEV MP Turbine model.

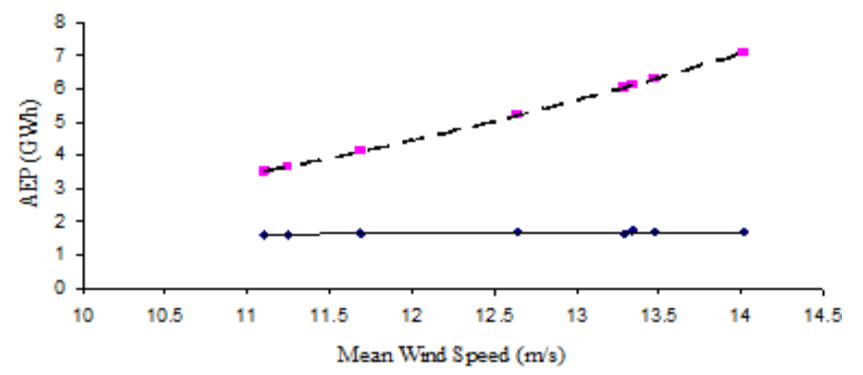

$$
\begin{array}{|l|}
\text { - Poly. (WAsP predicted AEP (GWh)) } \\
- \text { - Poly. (Boyle's prediction AEP (GWh)) }
\end{array}
$$

Figure 10. The WAsP and Boyle derive AEP curves for GEV MP

Table 4 also illustrates that six FL 80 WTGs produced 42 MWh less energy than four FL 120 WTGs. The COE borne by the FL120 model was less as well. This was perhaps due to the fact that there are economies of scale in wind turbines i.e. larger wind machines are usually able to deliver electricity at a lower cost than smaller machines. The reason is that the cost of foundations, road building, electrical grid connection, plus a number of components in the turbine are somewhat independent of the size of the machine [6]. Distribution of wind speeds and energy content of the wind speeds should be looked into to determine the ideal combination of the size of the rotor and the size of the generator at different wind turbine sites.

\subsection{Environmental Issues}

The primary environmental value of electricity generated from wind energy systems is that the wind offsets emissions that would be generated by conventional fossil fueled power plants. These emissions include sulfur dioxide $\left(\mathrm{SO}_{2}\right)$, oxides of nitrogen $\left(\mathrm{NO}_{\mathrm{x}}\right)$, carbon dioxide $\left(\mathrm{CO}_{2}\right)$, particulates, slag and ash [12]. There are also benefits associated with wind energy production other than the direct environmental ones. These include such indirect benefits as improved public health and benefits that would accrue by reducing oil imports. Whilst there are a number of environmental benefits to wind energy there are also some associated issues which must be carefully considered in planning projects. It is vitally important that projects are properly and sensitively integrated into the landscape and developed in consultation with local communities. Only in this way will public support be maintained and strengthened and the potential of wind to contribute to our electricity needs to be met. The scale of developments should be in keeping with the nature of the landscape and the distribution of habitation within it. Some sites may be appropriate for larger wind farms, others only for smaller ones. The principle environmental issues to be considered in deploying wind turbines are the visual and landscape impact, noise emissions, electromagnetic interference and effects upon birds and wildlife [13].

Large systems may be unappealing from an aesthetic viewpoint, particularly around scenic or seashore recreational areas. However, turbines of same type, size and equal number of blades provides a clean, simple and repetitive view. Like any other rotating mechanical systems, wind turbines also create some noise during their operation. Noise is essentially a sign of inefficiency and manufacturers have reduced noise generation intensities over the years. Additionally, proper siting and insulating materials can be used to minimise noise impacts. 


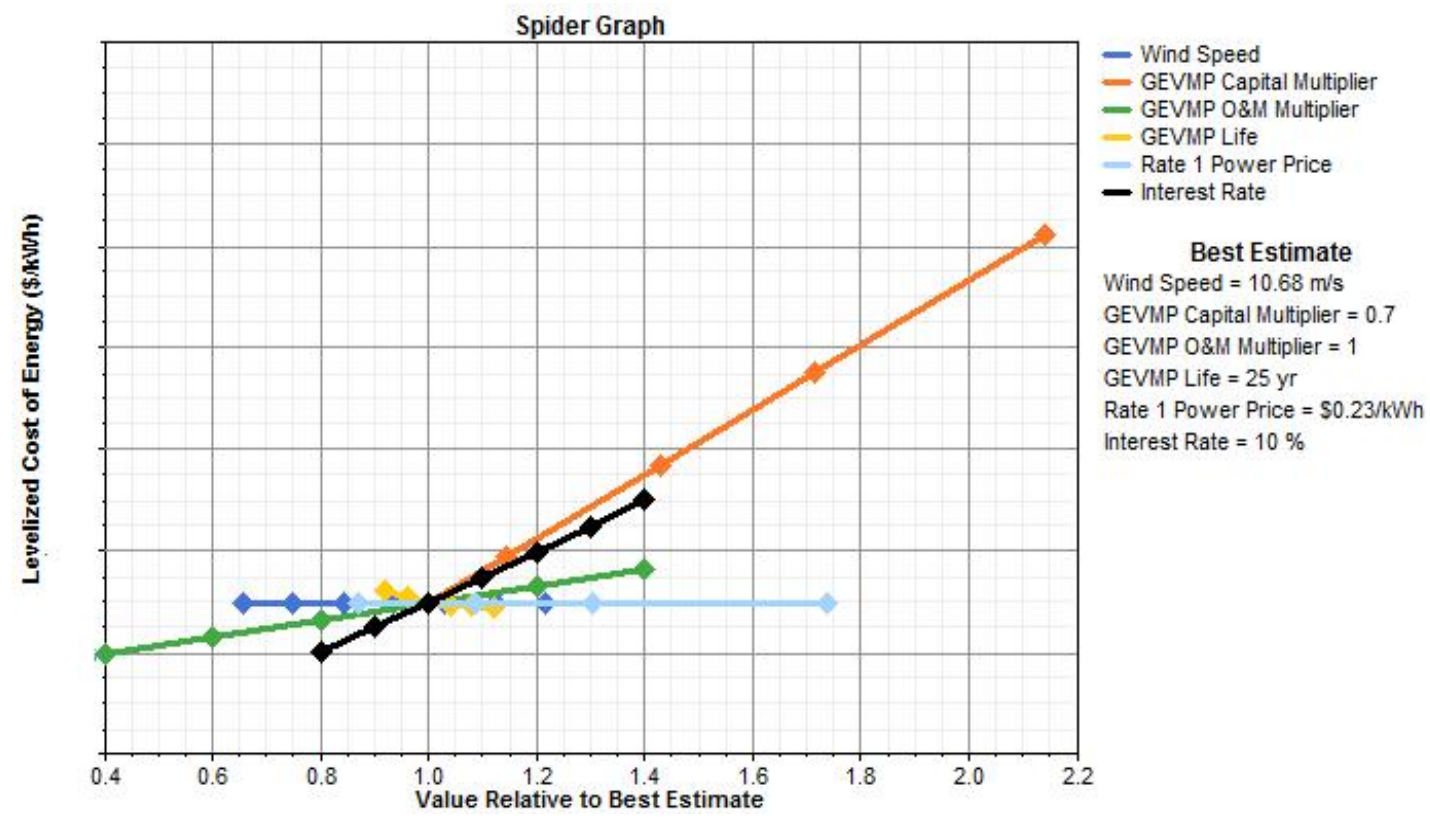

Figure 11. A computer simulation for the Sensitivity of cost of electricity to various parameters for GEV MP $275 \mathrm{~kW}$ WTG.

TV, FM and Radar waves are perturbed in line of sight by electrically conducting materials. Therefore, the metallic parts of rotating blades can produce dynamic interference in signals [11]. It is recommended that wind turbines are not placed between sending and receiving equipment of radio waves. In small domestic situations, interference of TV signals may be disturbing; therefore this should be taken into consideration during the planning stages.

Lastly, the problem of bird kills has been independently studied all over the globe confirming that bird strikes caused by wind turbines actually do take place. Studying the migratory patterns of the bird species and careful turbine placement can prevent the majority of fatalities.

\section{Conclusions}

The OWC, digitized map, and the obstacle groups were utilized by the WAsP software to determine the wind regime available in Vadravadra, Gau. The Southern Eastern sides of the island appear to be promising for wind electricity generation using Vergnet $275 \mathrm{~kW}$ wind turbines where wind power density at a height of $50 \mathrm{~m}$ or higher is found to be around $1128 \mathrm{~W} / \mathrm{m}^{2}$ annually. The total energy produced from using eight Vergnet $275 \mathrm{~kW}$ WTGs was $13.320 \mathrm{GWh}$ and the COE borne was $\$ 0.55 / \mathrm{kWh}$. With the price of petroleum based oils increasing regularly, the Vergnet may become a sound investment for Fiji. FEA, themselves could invest in this project as they spend $\$ 98.6$ million on diesel fuel for its generators every year [2]. It can also be noted that six FL 80 WTGs produced 42 MWh less energy than four FL 120 WTGs. The COE borne by the FL120 model was less as well. The rated production capacity of both installations was same. It is widely considered that there are economies of scale in wind turbines i.e. larger wind machines are usually able to deliver electricity at a lower cost than smaller machines. This is an important finding as there are many difficulties in land security in the country. Energy produced per unit area of land used for turbine installations should be maximized.

Further study such as this should be carried right throughout the nation. Additional wind speed data at various locations around Fiji should be measured and WAsP modeling for these areas must be done so that a wind atlas for Fiji may be created. This would encourage and enable future wind-farmers to properly assess their potential turbine sites.

The importance of renewable energy and in particular wind power in the South Pacific region is gaining prominence. The results from this work may be used as a basis to understand and appreciate the potential of the wind regime on the many rugged volcanic islands in Fiji.

\section{Acknowledgements}

The substantial support and guidance provided by Dr Ajal Kumar of the Physics Division, USP, during the course of the project is recognised and appreciated. The Fiji Department of Energy is acknowledged for providing the initial windspeed and direction data.

\section{REFERENCES}

[1] WWEA. World Wind Energy Report, http://www.2009wwec.net/report2008_final.pdf [accessed 21.10.09].

[2] FEA. 2008. Annual report. Available from: http://www.fea.com.fj [accessed 02.11.09]. 
[3] Prasad, R. (2007). Assessment of wind resources and Analysis of Wind Data for some locations in Fiji .MSc Theses, University of the South Pacific. Retrieved 20.10.09

[4] Demirbas_A (2002).. Turkey's energy overview beginning in the twenty-first century. Energy Convers Manage;43:1877-87.

[5] Bowen, A.J. and N.G. Mortensen (1996). Exploring the limits of WAsP: the Wind Atlas Analysis and Application Program. Proceedings of the 1996 European Union Wind Energy Conference and Exhibition, Göteborg, Sweden, November $20-24,584-587$

[6] Ahmed Shata AS, Hanitsch R. (2006). Evaluation of wind energy potential and electricity generation on the coast of Mediterranean Sea in Egypt. Renew energy;31:1183-202.

[7] Mortensen, N, G., Heathfield, D, N., Myllerup, L., Landberg, L., \& Rathmann, O. (2004). Getting started with WAsP 8 , Riso National Laboratory, Roslilde. Denmark.mm
[8] Rehman S, Halawnai TO, Mohandes M. (2003). Wind power cost assessment at twenty locations in the Kingdom of Saudi Arabia. Renew Energy;28:573-83.

[9] Troen, I. and E.L. Petersen (1989). European Wind Atlas. ISBN 87-550-1482-8. Risø National Laboratory, Roskilde. $656 \mathrm{pp}$.

[10] Boyle G. (2002). Renewable energy: power for a sustainable future. 2nd ed. UK: Oxford University Press;

[11] Kumar, A and S. Prasad. (2009) . Examining wind quality and wind power prospects on Fiji Islands. Renew Energy. pp 536-540

[12] SOPAC .(2009) Wind Energy and its Potential in the Pacific Islands. SOPAC Miscellaneous Report 559, Fiji, pp 30-36

[13] Manwell, J.F., J.G McGowan and A.L Rogers. (2002). Wind Energy Explained. Theory, Design and Application, John Weily and Sons Ltd, England. pp 420-9 